Anna Wilk*

\title{
MITY JAKO „KOLEKTYWNE DOŚWIADCZENIA” W NIEMIECKIEJ REPUBLICE DEMOKRATYCZNEJ - NA PRZYKLADZIE WYBRANYCH UTWORÓW HEINERA MÜLLERA ${ }^{1}$
}

Mimo upływającego czasu i licznych współczesnych tematów, które mogą inspirować pisarzy, mity wciąż należą do bardzo popularnych motywów literackich. Wydaje się, że Bertolt Brecht słusznie postrzegał mitologię, jako skarbiec bez dna, z którego można czerpać bez ograniczeń i całymi garściami. Twórca teatru epickiego często nie odczuwał nawet potrzeby adnotacji nawiązań mitologicznych, postrzegając mity jako dorobek kulturowy, z którego korzysta się w sposób zauważalny dla każdego w miarę wykształconego czytelnika. Niniejszym stosowanie przypisów było zdaniem Brechta w wielu przypadkach zbędne, gdyż odniesienia do znanych dzieł literatury antycznej (np. Eurypidesa, Sofoklesa) czy światowej (np. Szekspira) były nazbyt oczywiste, i stanowiło czerpanie ze światowego dorobku kulturowego. Twórczość Brechta i jego podwaliny teatru epickiego należały również do kręgu zainteresowań innego niemieckiego dramaturga, Heinera Müllera.

Heiner Müller, urodzony w roku 1929 w Eppendorf, należy do najwybitniejszych i najbardziej cenionych przedstawicieli literatury Niemieckiej Republiki Demokratycznej. Jego pierwsze próby pisarskie datowane są na początki NRD. Podczas gdy ojciec Kurt Müller, matka Ella i młodszy brat Wolfgang udali się w roku 1951 ze względów politycznych do RFN, Heiner Müller postanowił pozostać i ,ustatkować” jako pisarz. „,[M]imo wielu okazji nie zdecydował się nigdy opuścić Niemieckiej Republiki Demokratycznej, traktując swoje życie jako materiał do teatru, który musi odzwierciedlić i wykorzystać dla przyszłości jedyne w swoim rodzaju doświadczenie podzielonych Niemiec i podzielonej Europy" (Muskała 2000, s. 191). Podążając za podziałem wyznaczonym przez Wolfgan-

* Dr Anna Wilk, Uniwersytet Łódzki, Instytut Filologii Germańskiej, ul. Pomorska 171/173, 90-236 Łódź, e-mail: anna.wilk@uni.lodz.pl.

${ }^{1}$ Niniejszy artykuł ukazał się w 2017 roku w thumaczeniu Łukasza Plęsa na język angielski: Myths as ,Collective Experiences” in the German Democratic Republic on the Example of Chosen Works by Heiner Müller, [w]: Małgorzata Budzowska, Burc Idem Dincel, Jadwiga Czerwińska and Katarzyna Chiżyńska (ed.), The Metamorphoses of Ancient Myths. Frankfurt am Main, s. 149-158. 
ga Schivelbuscha wielu literaturoznawców wyznacza trzy ważne fazy twórczości Müllera i dzieli je na:

- Produktionsstücke, sztuki produkcyjne, lata pięćdziesiąte, np. Der Lohndrücker (Obniżający zarobki) 1957, Die Korrektur (Korekta) 1957, opisujące m.in. pracę i warunki bytowe w państwie socjalistycznym,

- Antikenstücke, sztuki antyczne, lata sześćdziesiąte, np. Philoktet (Filoktet) 1961, Der Horatier (Horacjusz) 1968, Mauser 1970, Sophokles/ Ödipus Tyrann (Sofokles/Edyp Tyran) 1966/67, Herakles 5 1964, Verkommenes Ufer Medea Material Landschaft mit Argonauten (Gnijacy brzeg Materiaty do Medei Krajobraz z Argonautami) 1982,

- Deutschlandstücke, sztuki o Niemczech, lata siedemdziesiąte, np. Germania Tod in Berlin (Germania Śmierć w Berlinie) 1971, Wolokolamsker Chaussee I-V (Szosa Wołokołamska I-V).

Jak podkreśla Wolfgang Emmerich, ten przejrzysty podział twórczości Müllera nie zawsze odpowiada rzeczywistości i często wykracza poza wyznaczone ramy czasowe (por. Emmerich 1990, s. 141). Dobrym przykładem takiej 'niekonsekwencji' jest zainteresowanie Müllera mitem Medei, gdyż jej literackiej adaptacji poświęcił więcej niż jeden utwór. Zajmował się tą problematyką trzykrotnie - po raz pierwszy w roku $1972 \mathrm{w}$ dramacie Zement (Cement), w którym jedna ze scen zawiera wskazówkę: Medeakommentar; dwa lata później napisał pantomimę Medeaspiel; w końcu jego zainteresowanie mitem Medei znalazło wyraz w opublikowanym osiem lat później trzyczęściowym utworze Verkommenes Ufer Medea Material Landschaft mit Argonauten (Gnijacy brzeg Materiaty do Medei Krajobraz z Argonautami ${ }^{2}$. Łącznikiem pomiędzy jego dziełami wydaje się być historia Niemiec i Europy. Nawet w pozornie niezwiązanych z teraźniejszością sztukach inspirowanych antykiem, odnajdujemy aluzje do współczesnej autorowi sytuacji politycznej. Nie bez powodu, gdyż Müller postrzega mity jako „zakrzepłe, kolektywne doświadczenia, $\mathrm{z}$ drugiej strony esperanto, międzynarodowy język, rozumiany już nie tylko w Europie". Niniejszym mity są pojmowane jako uniwersalne treści, zrozumiałe niezależnie od danego kręgu kulturowego ${ }^{3}$. Tym językiem posługiwał się niemiecki dramaturg, aby skłonić do refleksji i w zawoalowany sposób opowiedzieć o problemach, z którymi w tamtych czasach się zmagano. W niniejszym artykule zostanie podjęta próba prześledzenia funkcji mitu na przykładzie dramatów Philoktet (Filoktet) i Der Horatier (Horacjusz) Heinera Müllera.

Historia Filokteta, wodza rozsławionego w wojnie trojańskiej, uczestnika wyprawy Atrydów, ma wiele wariantów. Według mitycznych podań, Filoktet brał

\footnotetext{
${ }^{2}$ Fragment poświęcony podziałowi twórczości Heiner Müllera został zaczerpnięty z mojej rozprawy doktorskiej: Anna Zaorska: „,Moje zbrodnie sq owocem miłości”. Mit Medei w literaturze niemieckiej.

${ }^{3}$ Müller H., 1992, Krieg ohne Schlacht. Leben in zwei Diktaturen, Köln, s. 321. [Tłum. A.W.].
} 
udział w wyprawie, której celem było odzyskanie Heleny, żony Menelaosa. Podczas tej wyprawy poznał Heraklesa i uwolnił go od cierpień zadanych mu przez żonę Dejanirę. Za podpalenie stosu pogrzebowego otrzymał w podzięce „cudowny łuk i strzały zatrute krwią Hydry lerneńskiej” (Chodkowski 2009, s. 259). Można przypuszczać, że Filoktet był wspaniałym łucznikiem i dzielnym wojownikiem. Podczas uczty ofiarnej na greckiej wyspie Tenedos został ukąszony przez węża, rana zaczęła ropieć i wydzielać nieprzyjemny zapach. Towarzysze wyprawy nie byli w stanie znieść smrodu i krzyku Filokteta, dlatego nie bacząc na jego wcześniejsze zasługi pozostawili go w osamotnieniu na wyspie Lemnos. Zgodnie z przepowiednią dzięki Filoktetowi losy wojny trojańskiej mogły ulec zmianie, dlatego Odyseusz (lub według innych podań Diomedes) powrócił na Lemnos, starając się pozyskać jego wsparcie i łuk. Ten wątek historii podejmuje Sofokles w swoim opublikowanym w 409 roku p.n.e. dramacie zatytułowanym od imienia głównego bohatera Filoktet i to na tymże dziele greckiego tragika bazując sporządził swój utwór Heiner Müller. Niemiecki dramaturg podaje w swojej autobiografii Krieg ohne Schlacht [Wojna bez bitwy], że zainteresowanie mitem o Filoktecie sięga lat pięćdziesiątych, kiedy to powstał wiersz zadedykowany mitycznemu bohaterowi (por. Müller 1999, s. 188). Pierwsza scena datowana jest na rok 1953, całość została ukończona w roku 1961, natomiast opublikowana dopiero w 1965 w czasopiśmie „Sinn und Form” [,,Sens i forma”] (por. Müller 1999, s. 189). Na swoją inscenizację teatralną Filoktet musiał jednak jeszcze poczekać.

Tworzenie w odległych odstępach czasu nie jest nowym sposobem pracy autora. Müller pisał niekiedy fragmenty tekstów w różnych etapach swojego życia, po czym łączył je w całość, tworząc swego rodzaju mozaikę, kolaż. Z tego względu utwory Müllera często nie są dziełem jednolitym, a o ostatecznym kształcie decydował proces twórczy, zdeterminowany poszczególnymi etapami życia autora; przykładowo Gnijący brzeg Materiały do Medei Krajobraz z Argonautami składa się z różnorodnych tekstów, pisanych na przestrzeni ponad trzydziestu lat. Filoktet jest pod tym względem tekstem dość jednorodnym, gdyż mimo że praca nad nim trwała wiele lat, stanowi jednolity korpus tekstowy i brakuje w nim tak chętnie stosowanej przez Müllera majuskuły. Tekst zawiera również znaki interpunkcyjne, których brakuje innym dramatom, co z jednej strony utrudniało odbiór tekstu, z drugiej zaś strony zachęcało do wypróbowania różnych wariatów czytania. Istotnym jest, że dramaturg ogranicza motywy mityczne i uwspółcześnia historię, poprzez pozbawienie jej wątków fantastyczno-religijnych. Autor koncentruje się na samym przebiegu akcji i ogranicza dramatis personce do trzech protagonistów: Odyseusza, Neoptolemosa i Filokteta. Brakuje zatem chóru z jego komentującą przebieg wydarzeń funkcją, Heraklesa i sług Odyseusza, co dodatkowo eksponuje osamotnienie Filokteta. Poprzez redukcję liczby postaci oraz braku rozwinięcia portretu psychologicznego bohaterów następuje również skoncentrowanie się na ich postawie ideologicznej. Według Uwe Schüttego wyeliminowanie postronnych osób odciągających uwagę widza sprzyja uwidocznieniu konfliktu klas. Zdaniem 
Schüttego centralnym problemem, zarówno w dziele Sofoklesa jak i Müllera, jest dysonans pomiędzy wymaganiami państwa a prawem do autonomii jednostki (por. Schütte 2010, s. 37).

W nawiązaniu do antycznej budowy dramatu także tekst Müllera zaczyna się od prologu, jednak jest to jedynie pozorne nawiązanie do klasycznej formy. Mianowicie nie ma w nim podziału na stasimony i epejsodia, nie ma podziału na akty, tekst ma budowę hermetyczną, zachowana zostaje jedność czasu, miejsca i akcji. Jedynie prolog nasuwa skojarzenia $\mathrm{z}$ antykiem, skojarzenia te zostają jednak natychmiast przerwane:

\author{
Odtwórca Filokteta w masce klowna \\ Panie i panowie, dziś z naszej epoki \\ Przeniesiemy się wspólnie w przeszłości pomroki \\ Kiedy człowiek człowieka nie znosił serdecznie \\ Toteż wojował często i żył niebezpiecznie. \\ Zaraz też wyznać chcemy: fatalnie się stało, \\ Że naszej sztuce zabrakło morału \\ I nic się z niej na co dzień nie przyda nikomu. \\ Kto chce spasować, może iść do domu. \\ Drzwi Sali otwierają się na oścież. \\ To ku przestrodze. \\ Drzwi zamykaja się. Klown zdejmuje maskę, jego głowa \\ Okazuje się trupią czaszką. (Müller 1976, s. 75)
}

Wprowadzenie sugeruje innowację, nie będzie to typowa adaptacja mitycznej materii. Już na wstępie zostaje zasygnalizowany anachronizm i zestawienie różnych czasoprzestrzeni. Idąc śladem Brechta autor przypomina publiczności, że sytuacja na scenie jest jedynie przedstawieniem teatralnym a jednocześnie intryguje spostrzeżeniem, że sztuka nikomu się nie przyda, gdyż brakuje jej morału. Prolog łączy cechy komedii i tragedii. Odtwórca głównej roli pojawia się w masce klowna, mówi zaś o nienawiści i wojnach, pod maską klowna kryje się trupia czaszka. Autor w swoich sztukach często bazuje na kontrastach, które dodatkowo podkreśla i uwypukla. Można stwierdzić, że styl Müllera cechuje zestawianie scen i redukcja portretu psychologicznego bohaterów, bądź też nawet samo ograniczenie do przebiegu akcji. Jak dramaturg wyjaśnia w Trzech punktach odnośnie Filokteta, akcja jest modelem, a nie historią. Celem jest ukazanie postaw a nie znaczenia (por. Müller 1989, s. 61). Zdaniem Müllera przebieg wydarzeń jest niekwestionowany tylko wówczas, kiedy nie podważa się systemu. Dalej stwierdza: „Tylko Klown może zakwestionować cyrk” (Müller 1989, s. 61), a Filokteta, Odyseusza i Neoptolemosa określa mianem klownów i zarazem gladiatorów swego światopoglądu (por. Müller 1989, s. 61).

Po uwspółcześnionym prologu akcja przenosi się na wyspę Lemnos, którą zamieszkuje główny protagonista. Odyseusz i Neoptolemos obmyślają plan, którego celem jest skłonienie bohatera do opuszczenia greckiej wyspy i udania się pod 
Troję. Müller pozbawił swój dramat wielu wątków mitycznych, ale przejął fabułę i imiona protagonistów. O cudownym łuku nie ma mowy, jego funkcja zostaje zredukowana wyłącznie do narzędzia walki. Nie ma także mowy o wieszczu Helenosie, który „przepowiedział Grekom, iż do zdobycia Troi potrzebna jest obecność Filokteta" (Chodkowski 2009, s. 261). Filoktet w wersji müllerowskiej potrzebny jest jako wódz i bohater, który zagrzeje oddziały do walki. Odyseusz i Neoptolemos słusznie spodziewają się napotkać na opór i niechęć ze strony mieszkańca Lemnos. Pozostawiony w samotności na wyspie stał się typem nieufnym i asocjalnym, wrogo nastawionym do Greków. Jak spostrzega Uwe Schütte, w dramacie brakuje pozytywnych bohaterów (por. Schütte 2010, s. 38), a Otto Norbert Eke odnotowuje, że dramat bazuje na uczuciu nienawiści (por. Eke 1999, s. 108). Filoktet nienawidzi Odyseusza, który go opuścił i skazał na banicję. Swojego sprzymierzeńca nienawidzi jednak również sam Neoptolemos, przez którego ojciec Neoptolemosa został pozbawiony majątku. Odyseusz w cyniczny sposób wykorzystuje sytuację do rozgrywki politycznej. Tym samym zgodnie z zamysłem Müllera wyłaniają się trzy odmienne typy zachowań: Filoktet jest podmiotem złamanym na skutek dyktatu celów politycznych, Neoptolemos jest podmiotem działającym w imię wyższych wartości, moralistą, który odstępuje od reprezentowanych przez siebie wartości, Odyseusz jest podmiotem działającym w imię celów politycznych, którym, kierując się zasadą „cel uświęca środki”, przypisuje nadrzędną rangę (por. Eke 1999, s. 107). W centrum wydarzeń znajduje się konflikt pomiędzy różnymi racjami: pomiędzy etyką subiektywną i obiektywną, wolnością a koniecznością, moralnością a przymusem działania (por. Eke 1999, s. 106). Andreas Moser słusznie twierdzi, że istotniejszym od kwestii samopoczucia jednostki jest problem struktur (por. Moser 2014, s. 297), a Ralph Fischer zaznacza, że rana Filokteta oznacza destabilizację struktur i lukę w systemie (por. Fischer 2012, s. 87).

Konflikt wewnętrzny najbardziej został uwidoczniony w postaci Neoptolemosa, który raz kieruje się swoimi moralnymi zasadami, raz podąża za obranymi celami politycznymi. W chwili słabości wyznaje prawdę:

NEOPTOLEMOS: Poznaj więc prawdę. Nie chcę dłużej kłamać.

Bez twej drużyny nie zdobędziem Troi.

A tylko ty ją z naszą wojną wiążesz

Swoim rozkazem. By z wielkiej niedoli

$\mathrm{Ku}$ większej sławie zabrać cię pod Troję

Przebyłem morze i wbrew moim chęciom

Jam cię oszukał, już oszukanego

Sam wcześniej jeszcze będąc oszukanym.

Nie było wyjścia: skłamałem bom musiał.

Człowieku z Lemnos, oto cała prawda

Com ją niechętnie na języku nosił:

Tam za tą skałą czeka Odyseusz

Wróg twój i mój wróg, to jedno jest prawdą:

Gdy Troja padnie, on z mej ręki zginie [...] (Müller 1976, s. 89) 
Zwrot Neoptolemosa ku Filoktetowi jest jednak chwilowy. Gdy dostanie się w posiadanie łuku, znów stanie ramię w ramię z Odyseuszem. Ten zwrot ku synowi Laertesa wynika z pragmatyzmu: Filoktet wzbrania się dobrowolnie pomóc Grekom, podczas gdy Neoptolemos zdecydowany jest walczyć z wrogami nawet jeśli droga do sławy będzie oznaczała hańbę. Jeśli zajdzie taka konieczność zdecydowany jest również zmusić siłą mieszkańca Lemnos do opuszczenia wyspy. O tym, że wciąż odczuwa konflikt wewnętrzny, świadczy scena, w której oddaje Filoktetowi jego własność, mówiąc: „Bierz, zanim znów mnie język jego zmami” (Müller 1976, s. 99). Jak zauważa Eke, to nie tyle współczucie, co raczej wstyd z powodu utraty własnej moralnej integralności, zranione poczucie własnej wartości i nienawiść skierowana ku posiadającemu sztukę przekonywania Odyseuszowi skłania Neoptolemosa do oddania łuku i zwrócenia się na drogę prawdy (por. Eke 1999, s. 109). Ostatecznie to jednak Neoptolemos jest tym, który podstępnie pozbawia życia Filokteta, ratując przed śmiercią Odyseusza, w którym upatruje rzeczywistego ratunku dla Troi. Filoktet ginie ugodzony mieczem w plecy. Zaznaje mało bohaterskiej śmierci, w wyniku której z ofiary przeobraża się w męczennika. Jak słusznie stwierdza Karol Sauerland, wyprawa Odyseusza i Neoptolemosa na wyspę Lemnos ujawnia funkcjonowanie mechanizmów władzy. Przykład Neoptolemosa uwidacznia, do „,zego prowadzi 'system potrzeb i konieczności'”, który - zdaniem Sauerlanda - aż nazbyt szybko nabrał nowych „cnót” (Sauerland 1976, s. 111).

Po zamordowaniu Filokteta Odyseusz wpada na pomysł, jak martwy Filoktet mógłby dopomóc sprawie. Zmyśla historię, jakoby Trojanie chcieli przeciągnąć Filokteta na swoją stroną. Wedle tejże wersji, gdy bohater pozostał wierny towarzyszom, Trojanie uśmiercili go:

\author{
Nas mianowicie, Trojanie ubiegli \\ Bo go pragnęli przeciw nam pozyskać \\ A że był wierny, zabili go bowiem \\ Nie mogli złotem nic u niego wskórać \\ Ani gadaniem ani groźbą. Więc zginął \\ Na naszych oczach, gdyśmy otoczeni \\ Przez siedmiu Trojan walczyli z przybojem \\ Podczas gdy ósmy wbił mu miecz swój w plecy [...] (Müller 1976, s. 104-106)
}

na co Neoptolemos stwierdza:

Jeśli on zbędny, tyś także zbyteczny.

Idąc $w$ twe ślady sam siebie zdeptałem

Stałem się kłamcą, złodziejem, mordercą

Dobrze widziałem: zabito was obu. (Müller 1976, s. 106)

Przedstawiona scena uwidacznia brak poszanowania praw jednostki, tym razem prawa do pośmiertnego spokoju. Nawet martwy Filoktet jest w stanie przysłużyć się państwu, wskutek czego jego zwłoki mają zostać wykorzystane 
w cyniczny i wyrachowany sposób. Ostatecznie Odyseuszowi udaje się ocalić życie i odwieść Neoptolemosa od zgubnego pomysłu zabicia go. Odchodząc z martwym Filoktetem na plecach Odyseusz obiecuje zdradzić Neoptolemosowi pod Troją, jak mógł sytuację rozegrać i go zabić, nie ściągając na siebie podejrzeń.

Podczas gdy w postawie Filokteta czy Neoptolemosa doszukiwano się pozytywnych modeli zachowań, Odyseusz był na ogół osądzany negatywnie. „Z polskich znawców w roku 1930 Stanisław Witkowski podkreślił, że Odyseusz w ujęciu Sofoklesa to nie tylko człowiek 'bez skrupułów, mistrz intrygi, chytry i podstępny' ale i uosobienie 'racji państwowych"'. Na taką samą tendencję w odbiorze wskazuje również Heiner Müller, który zauważa, że Odyseusza postrzegano jako łotra, ucieleśnienie zła, stalinistę. Dla Müllera jest on zaś po prostu człowiekiem z pogranicza postaw, przypadkiem granicznym.

Zakończenie sztuki jest zgoła pesymistyczne, gdyż wygrywa obłuda, cynizm i kłamstwo. Moralność jednostki ginie w politycznym pragmatyzmie, a jednocześnie należy podkreślić, że to ludzie doprowadzają to takiego zakończenia. Deux ex machina czy transcendentalne wątki przyczynowo-skutkowe nie mają u Müllera zastosowania. Deprymujące jest również pozbawienie człowieka indywidualności i zredukowanie jego roli do funkcji pragmatycznych.

W didaskaliach Heiner Müller zwraca uwagę na aktualność poruszanych w sztuce problemów i sugeruje potencjalnym reżyserom możliwe sposoby inscenizacji. Podług koncepcji Müllera odejściu Odyseusza i Neoptolemosa z martwym Filoktetem powinny towarzyszyć projekcje zdjęć z różnych wojen: od wojny trojańskiej aż po wojnę w Japonii. Tym samym Müller po raz kolejny przypomina, że nie chodzi mu o historię, lecz o modele zachowań. Opisuje kolektywne doświadczenia, które są ponadczasowe, gdyż „w ostatnich stuleciach conditio humana zmieniła się tylko nieznacznie. Rozwój człowieka jako przedmiot antropologii jest absolutnie minimalny"4.

Innym dramatem, w którym mimo antycznej stylizacji można odnaleźć aluzje do sceny politycznej w NRD, jest dramat Der Horatier (Horacjusz). Utwór rozpoczyna się od sporu o władzę pomiędzy Rzymem i Albą. Aby uniknąć rozlewu krwi, miasta decydują się wystawić do walki swoich reprezentantów. Rzucone losy wyznaczyły do walki za Rzym Horacjusza, za Albę Kuracjusza. Ze względu na konotacje rodzinne (Kuracjusz jest narzeczonym siostry Horacjusza), spytano wojowników, czy nie proszą o ponowne rzucenie losów, czemu wyznaczeni do boju stanowczo się sprzeciwili. W wyniku walki spór na korzyść Rzymu rozstrzygnął Horacjusz. Mimo błagań Kuracjusza: „Oszczędź pokonanego. Twoja siostra/ Jest mą narzeczoną” (Müller 1978, s. 96) Horacjusz odrzekłszy: „Moja narzeczona ma na imię Rzym" (Müller 1978, s. 96), przebił przeciwnika mieczem i krew polała się „,strugą na ziemię” (Müller 1978, s. 96). W utworze Müllera krew

${ }^{4}$ Cyt. za: Heiner M., 1990, Material. Texte und Kommentare, ed. F. Hörnigk, Leipzig, s. 142. [Tłum. A.W.]. 
niejednokrotnie się przeleje. Po powrocie do ojczyzny Horacjusz zabija siostrę, która opłakiwała poległego narzeczonego, mówiąc:

Idź do tego, którego miłujesz bardziej niż Rzym.

I biada każdej Rzymiance

Która nad grobem wroga zapłacze.

I pokazał Rzymianom miecz dwukrotnie skrwawiony

I thumy umilkły [...] (Müller 1978, s. 97)

W utworze Müllera nie ma spisu osób ani typowego dla dramatu podziału na role, wszelkie dialogi wkomponowane są w korpus tekstu. Utwór przypomina dzięki temu zabiegowi pradawną wersję mitu przekazywaną w formie ustnej. Mord na siostrze wprawia ludzi w osłupienie. Pojawia się pytanie o wydźwięk moralny postawy bohatera i o dalsze przekazywanie jego historii. „Czy jako zwycięzca ma być uwieńczony,/ Czy jako zbrodniarz stracony[...] (Müller 1978, s. 97). Zebrani dochodzą do konkluzji: Horacjusz zostanie uhonorowany jako zwycięzca i stracony jako morderca. Na pytanie „Jakie imię nosić będzie Horacjusz w przyszłości” (Müller 1978, s. 101) lud jednomyślnie odrzekł:

\author{
Imię zwycięzcy nad Albańczykami \\ Imię mordercy swojej własnej siostry. \\ W jednym zdaniu zasługa i wina. \\ A kto winę jego przypomni a przemilczy zasługę, \\ Ten niech żyje pośród psów. \\ A kto zasługę wspomni a zapomni o winie, \\ Ten niech żyje również pośród psów. \\ Kto zaś w jednej godzinie wspomni jego winę \\ A w drugiej jego zasługę, \\ Mówiąc raz to, raz tamto tym samym językiem \\ O różnej porze i do różnych uszu, \\ Temu niech język będzie z ust wydarty, \\ Albowiem słowa muszą zostać czyste. \\ Bo można miecz złamać i można złamać \\ Człowieka, wszelako słowa \\ Wpadają bezpowrotnie w tryby świata (Müller 1978, s. 101)
}

Dramatopisarz stawia tym samym istotne pytanie o problem przekazywania historii. Uwe Schütte określa dramat Müllera mianem ,politycznej diagnozy czasu w otoczce mitologicznej" (por. Schütte 2010, s. 36), wskutek czego wysuwa analogię do tematu tabu: stalinizmu (por. Schütte 2010, s. 36). Schütte widzi w utworze głos samego autora, który zdaje się nawoływać do tego, aby polityczny sukces nie przysłonił ofiar, które utorowały drogę do zwycięstwa (por. Schütte 2010, s. 41). Tym samym z jednej strony ukazuje, że nie istnieje czyste rozgraniczenie pomiędzy winą a zasługą, z drugiej, że w pamięci kolektywnej po zwycięstwie los ofiar i negatywne skutki polityki nie mogą być przemilczane (por. Schütte 2010, 
s. 41). Sedno w tym, że zarówno uhonorowanie bezwzględnego mordercy, jak i stracenie zasłużonego bohatera, nie stanowią satysfakcjonującego rozwiązania. Jak puentuje Schütte, z tym paradoksem trzeba żyć (por. Schütte 2010, s. 41).

Również w Horacjuszu brakuje rozwinięcia portretów psychologicznych bohaterów, wyraźne jest natomiast dążenie do uwypuklenia samej postawy oraz związanej z nią refleksji. Wedle wskazówek Müllera bohaterom, mieszkańcom obu miast i ich reprezentantom należy założyć maski, tak jakby autor chciał zapobiec procesowi identyfikowania się z którąś ze stron. Aktorzy, którzy odegrali swoje role winni pozostać na scenie i wcielić się w inną postać (por. Müller 1978, s. 101).

Pisarze Niemieckiej Republiki Demokratycznej często sięgali do mitycznych podań, aby w zakamuflowany sposób przemycić zakazane tematy i obejść cenzurę. W jednym z wywiadów także Heiner Müller przyznaje, że była to próba podniesienia istotnych pytań na temat okresu socjalizmu:

Nie chcę dziś pisać sztuki antycznej, ani też dokonywać adaptacji antycznego tematu. Ale we wczesnych latach sześćdziesiątych nie wolno było pisać sztuk o stalinizmie. Potrzebny był tego rodzaju model, jeśli chciało się postawić naprawdę ważne pytania. Tu ludzie chwytają to $\mathrm{w}$ lot. $^{5}$

Utwory Müllera stawiają pytanie o kondycję człowieka we współczesnym świecie, odnosząc się krytycznie do polityki imperialistycznej i kapitalistycznej. Sięgając do mitu o Filoktecie autor przedstawił pesymistyczną wizję świata: z jednej strony pragnący wyrwać się z osamotnienia i marazmu Filoktet, z drugiej Odyseusz i Neoptolemos z polityką terroru i zakłamania. Filoktet próbuje się uwolnić, wyemancypować jako człowiek, ale jego wysiłki pozostają bezskuteczne. Opozycje: dialektyka rozumu versus terror, jednostka versus władza, prawda versus kłamstwo, moralność versus pragmatyzm determinują cały utwór. Te same opozycje będą widoczne również w Horacjuszu, w którym pobrzmiewać będzie jeszcze pytanie o formę przekazywania pamięci. Sztuki Müllera są zdaniem Norberta Otto Ekego zarówno dramatem 'historycznym' jak i współczesnym (por. Eke 1999, s. 114). Osadzenie akcji w mitycznych realiach jest pozorne, gdyż jak zauważa Joanna Jabłkowska:

Müller uses myth as a type of "alienation effect" ("Verfremdungseffekt"). He does not "adapt" myths but quotes them as archetypical examples of recurring social situations and exposes not only the cynical and pragmatic GDR system, but also the "Western" instrumentalisation of values for ad hoc political or economic purposes. (Jabłkowska 2014, s. 139)

${ }^{5}$ Cyt. za: Emmerich W., 1990, Der vernünftige, der schreckliche Mythos. Heiner Müllers Umgang mit der griechischen Mythologie, [w:] Müller H., Material. Texte und Kommentare, ed. F. Hörnigk, s. 142. [Tłum. A.W.]. 
Müller nie stara się o uwspółcześnienie swoich dramatów poprzez przeniesienie ich akcji do innej czasoprzestrzeni, lecz buduje paralelę pomiędzy przeszłością a teraźniejszością. Tym samym wymuszony zostaje na publiczności aktywny udział i wysiłek interpretacyjny. Co ciekawe, w myśl idei Brechta i jego „efektu wyobcowania" widz nie powinien identyfikować się z wydarzeniami na scenie, a jedynie je dostrzec i przeanalizować. Tym samym sztuki Müllera można zaliczyć w pewnym sensie do Lehrstücke, learning-play.

\section{BIBLIOGRAFIA}

Chodkowski R. (2009), Filoktet. Wstęp, [w:] Sofokles: Tragedie. Tom I. Ajas, Trachinki, Filoktet, Edyp w Kolonos (tłum. Chodkowski R.), Towarzystwo Naukowe Katolickiego Uniwersytetu Lubelskiego Jana Pawła II, Lublin, s. 259-302.

Eke N. (1999), Heiner Müller, Philipp Reclam, Stuttgart.

Emmerich W. (1990), Der vernünftige, der schreckliche Mythos. Heiner Müllers Umgang mit der griechischen Mythologie, [w:] Heiner Müller: Material. Texte und Kommentare, wyd. Hörnigk F., Reclam Verlag, Leipzig, s. 138-156.

Jabłkowska J. (2014), Antique Dramas by Heiner Müller. Adaptation of myths or a new dramatic aesthetics, [w:] Collectanea Philologica XVII, s. 137-148.

Moser A. (2014), Utopiekonzept und Geschichtsauffassung im Werk Heiner Müllers, Röhrig Universitätsverlag, St. Ingbert.

Müller H. (1976), Filoktet (thum. Jacek St. Buras), [w:] Literatura na Świecie 1/76, s. 74-107.

Müller H. (1978), Horacjusz (tłum. Jacek St. Buras), [w:] Dialog $n r$ 2, s. 96-102.

Müller H. (1989), Drei Punkte zu Philoktet, [w:] Heiner Müller: Material. Texte und Kommentare, wyd. Hörnigk F., Reclam Verlag, Leipzig, s. 138-156.

Müller H. (1999), Krieg ohne Schlacht. Leben in zwei Diktaturen, Kiepenheuer \& Witsch, Köln.

Muskała M. (2000), Ttumacz, ten sprawca zza biurka, [w:] Heiner M. Makbet, hamletmaszyna, anatomia Tytusa, (wyd. Buras J, Jeleń E., Muskała M.) Księgarnia Akademicka, Kraków.

Sauerland K. (1976), Smutna prawda, [w:] Literatura na Świecie 1/76, s. 108-111.

Schütte U. (2010), Heiner Müller, Böhlau Verlag, Köln.

Anna Wilk

\section{MYTHS AS „COLLECTIVE EXPERIENCES” IN THE GERMAN DEMOCRATIC REPUBLIC - EXEMPLIFIED IN SELECTED WORKS BY HEINER MÜLLER}

(Summary)

The writers of the German Democratic Republic often reached for myths to convey forbidden issues in an oblique way and to deceive the censors. In an interview Heiner Müller admits that this was an attempt to raise crucial questions about socialism:

I want neither to write ancient plays today nor to adapt ancient topics. In the early 1960s plays about Stalinism were forbidden. It was necessary to invent such a model to raise really important issues. So that people would recognize them at once. 
On the basis of the works Philoctetes and The Horatian the reception of two ancient myths will be followed in plays by Heiner Müller. The German playwright employs an interesting strategy: he adopts myths in varied, condensed forms, however, the plot is set in mythical circumstances. Müller does not make an attempt to modernize his dramas by transferring their content into a new setting of space and time, but he draws parallels between past and present. Müller's plays are in Norbert Otto Eke's opinion, both historical and contemporary. Interestingly, according to Brecht's idea and his ,alienation effect" the spectator should not identify with the events on stage, but only follow and analyse them. For this reason, the works by Müller can be qualified as didactic.

Keywords: Heiner Müller, myth in the literature, Philoctetes, Horatian 